\title{
EDUCATION OF SENSES AND SENSIBILITIES: BETWEEN THE TREND AND THE POSSIBILITY OF RESEARCH RENOVATION IN HISTORY OF EDUCATION ${ }^{12}$
}

\author{
DOI: http://dx.doi.org/10.1590/2236-3459/76625
}

\author{
Marcus Aurelio Taborda de Oliveira' \\ 'Universidade Federal de Minas Gerais (UFMG), Belo Horizonte/MG, Brasil
}

$\cos 80$

\begin{abstract}
The article, in a theoretical-historiographic perspective, discusses the current trend of studies on the history of education of the senses and sensibilities. It begins with the presentation of the theme "sensibilities" and its presence in different historiographical traditions, showing how this approach in the field of History is not new. Then, in its first part, it discusses the recent arrival of the theme in the debates of History of Education in Latin America. In the second part, it presents and situates a set of monographic studies developed by the Center for Studies on the Education of Senses and Sensibilities - Nupes, FAE/UFMG, in partnership with researchers from Brazil and other countries, discussing some of their basic assumptions. The text concludes by discussing the limits, risks, and scope of the history of education of the senses and sensibilities as a trend that balances between academic fad and the possibility of renovating the consecrated forms of investigating the past and the present of Latin American education.

Keywords: history of education, history of the education of senses and sensibilities, historiography.
\end{abstract}

\section{EDUCAÇÃO DOS SENTIDOS E DAS SENSIBILIDADES: ENTRE A MODA ACADÊMICA E A POSSIBILIDADE DE RENOVAÇÃO NO ÂMBITO DAS PESQUISAS EM HISTÓRIA DA EDUCAÇÃO}

\begin{abstract}
Resumo
O artigo, de caráter teórico-historiográfico, discute a voga atual de estudos sobre a história da educação dos sentidos e das sensibilidades. Inicia-se com a apresentação do tema "sensibilidades" e a sua presença em diferentes tradições historiográficas, mostrando como não é nova essa abordagem no campo da História. Em seguida, ainda na sua primeira parte, discute a chegada recente do tema nos debates da História da Educação na América Latina. Na segunda parte, apresenta e situa um conjunto de estudos de caráter monográfico desenvolvidos pelo Núcleo de Estudos sobre a Educação dos Sentidos e das Sensibilidades - Nupes, da FAE/UFMG, em parceria com pesquisadores do Brasil e de outros países, discutindo alguns dos seus pressupostos básicos. Finaliza o texto a problematização dos limites, dos riscos e do alcance da história da educação dos sentidos e das sensibilidades como uma voga que se equilibra entre o modismo acadêmico e a possibilidade de arejamento das formas consagradas de inquirir o passado e o presente da educação no âmbito latino-americano.
\end{abstract}

Palavras-chave: história da educação, história da educação dos sentidos e das sensibilidades, historiografia.

1 Translation by Viviane Coelho C. Ramos.

${ }^{2} \mathrm{~A}$ reduced version of this work was produced for the purpose of publication in the book chapter format, in the Spanish language, at the invitation of colleagues Pablo Pineau and Nicolas Arata, of the University of Buenos Aires. I thank colleagues for their kind authorization for publication in Brazil, in an enlarged version and as an article. 


\title{
EDUCACIÓN DE LOS SENTIDOS Y DE LAS SENSIBILIDADES: ENTRE LA MODA ACADÉMICA Y LA POSIBILIDAD DE RENOVACIÓN EN EL ÁMBITO DE LAS INVESTIGACIONES EN HISTÓRIA DE LA EDUCACIÓN
}

\section{Resumen}

El artículo, de carácter teórico-historiográfico, discute la actual ola de estudios sobre la historia de la educación de los sentidos y de las sensibilidades. Se inicia con la presentación del tema "sensibilidades" y su presencia en diferentes tradiciones historiográficas, señalando cómo no es nuevo ese enfoque en el campo de la historia. A continuación, aún en su primera parte, discute la llegada reciente del tema en los debates de la Historia de la Educación en América Latina. En la segunda parte, presenta y sitúa un conjunto de estudios de carácter monográfico desarrollados por el Núcleo de Estudios sobre la Educación de los Sentidos y de las Sensibilidades - Nupes, de la FAE/UFMG, en asociación con investigadores de Brasil y de otros países, discutiendo algunos de sus elementos básicos. Finaliza el texto la problematización de los límites, de los riesgos y del alcance de la historia de la educación de los sentidos y de las sensibilidades como una ola que se equilibra entre el modismo académico y la posibilidad arrojar nuevos aires en las formas consagradas de inquirir el pasado y el presente de la educación en el ámbito latinoamericano.

Palabras-clave: historia de la educación, historia de la educación de los sentidos y de las sensibilidades, historiografía.

\section{L'ÉDUCATION DES SENS ET DES SENSIBILITÉS: ENTRE LA VOGUE ACADÉMIQUE ET LA POSSIBILITÉ DE RENOUVELLEMENT DANS LE DOMAINE DE LA RECHERCHE EN HISTOIRE DE L'ÉDUCATION}

\begin{abstract}
Résumé
Dans cet article, de caractère théorique et historiographique, nous discutons l'actuelle vogue des études sur I'histoire de l'éducation des sens et des sensibilités. Nous commençons par la présentation du thème des "sensibilités» et sa présence dans de différentes traditions historiographiques, montrant que cette approche n'est pas nouvelle dans le domaine de l'Histoire. Ensuite, toujours dans la première partie, nous traitons de la récente arrivée du thème dans les débats de l'Histoire de l'Éducation en Amérique latine. Dans la deuxième partie, nous présentons et situons un ensemble d'études de caractère monographique développées par le Groupe d'Étude sur l'Éducation des Sens et des Sensibilités - Nupes, FAE/UFMG, en partenariat avec des chercheurs du Brésil et d'autres pays, en discutant certains de leurs hypothèses de base. Nous terminons le texte par la problématisation des limites, des risques et de la portée de l'histoire de l'éducation des sens et des sensibilités comme une vogue qui s'équilibre entre l'engouement académique et la possibilité d'aération des formes consacrées d'examiner le passé et le présent de l'éducation en Amérique latine.

Mots-clés: histoire de l'éducation, histoire de l'éducation des sens et des sensibilité, historiographie.
\end{abstract}




\section{History of the education of senses and sensibilities: a new field of studies?}
his is how Anne-Emmanuelle Demartini stars the entry Sensibilities, in the Dictionnaire de I'historien (GAUVARD; SIRINELLI, 2015):

\begin{abstract}
Sensibility and History: a new subject. I do not know a book which deals with this. I actually cannot see its multiple problems formulated anywhere". This proposition of Lucien Febvre, co-founder of Annales, in 1941, says a lot on how the theme sensibility has been, for a long time, out of history. The faculty of the subject to be affected by an exterior modification refers to a heterogeneous set of phenomena, more or less complex, dealing, simultaneously, with body and spirit: perception, sensations, feelings, and emotions. In this domain, the neglect of historians was fed by evidences related to the transcultural feature of emotions (all men would love, suffer, be happy, in the same way in all times), evidences that are now outdated. From now on, by the way, historians prefer to say on sensibilities. The plural better expresses the variable and collective character of social factors, completely cultural, that justifies the historic study. (p. 642).
\end{abstract}

The fact that this idea, as well as the one of senses, appear as entries in a recent specialized dictionary seems to prove that both, more than neutral and empty-meaning words, have stablished themselves in the lexicon of contemporary historians.

To those less familiar with it, the theme senses and sensibilities can seem new in the historiography debate. However, we can only think this if we forget many significant contributions, such as those of Johan Huizinga, in his fascinating The Autumn of Middle Ages from 1919. Or even those of Paul Zumthor (1993, 2005), Werner Jaeger (1986), Norbert Elias (1991), Mikhail Bakhtin (1999), Walter Benjamin (2008, 2009, 2012, 2013), Edward Thompson (1989, 1998), Carlo Ginzburg $(1989,2010)$ and many other references that can be done in this domain, in different historiographical traditions. However, one can suppose that it was Lucien Febvre (1985) the first to propose, in these terms, a concern with the sensibilities as a pressing matter of a social history of culture, already in the 1950s. Following his direction, Alain Corbin (2005) seems to be the busiest author in this domain, in the sphere of influence of the heirs of Annales. Nevertheless, Peter Gay (1989) certainly mobilized himself to study the history of sensibilities, especially in his monumental work in five volumes on Victorian culture. Thus, if we can think in a new and recent domain of studies in History of Education, we cannot forget that the subject has been the object of historians from different theoretical-methodological backgrounds for decades.

Regarding Latin America, although it would be necessary and prudent to investigate the historiographical tradition of each country, what cannot be done here, it is worthwhile to remember, at least, the work of Gilberto Freyre, from 1936, in Brazil, and the historical essays of the Colombian Willian Ospina (1999, 2008). But who, in fact, assumed without hesitation the term history of sensibilities was the Uruguayan José Pedro Barrán, in 1989.

A defining trace of this perspective of historical studies is its multi and transdisciplinary perspectives. If Febvre advocate the need to dialog with the field of Psychology, other authors previously mentioned developed their studies aiming Anthropology, Psychoanalysis, Historical Sociology, Philosophy, Linguistics, Aesthetic and, more recently, Neurosciences. Therefore, this study domain prompt us to broaden the channels of dialogue with the most diverse subject fields, what leads in part to its fascination and difficulties.

All these works, many already classics, even though not focused on history of 
education, show us ways of definition, mobilization, stabilization, and transformation of sensibilities, normally much more in tune with the education of body senses than with the pedagogical discourses and ideas. Thus, the emergency of a concern with the relations between culture and nature, with the material dimension of life and, consequently, with the corporality throughout history, be it in the school perspective and other educational instances, seems to have delimited this field of studies. So, one can recognize this history domain as one in which the body senses are constantly mobilized to define or transform the sensibilities, exactly as shown by José Barrán when suggesting the passing of a "barbaric" culture to the disciplining, in his previously mentioned work, but also as shown in the works of Sandra Pesavento (2005), or the studies collected by Brepohl et al. (2012).

Pesavento (2005) reminds us that the

[...] sensibility is another way to apprehend the world beyond scientific knowledge. The sensibilities would correspond to the primary core of perception and human experience translation that can be found in the center of the construction of a social imaginary. The sensitive knowledge operates as a way of recognition and translation of reality that sprouts not from what is rational or more elaborate mental constructions, but from the senses that come from the intimate of each individual. It is up to the sensibilities to assault the cognitive world, as they deal with the sensation, the emotional, the subjectivity, values and feelings that follow other logics and principles besides the rational ones. The sensibilities are a way of being in the world and staying in the world, going from the individual perception to the shared sensibility. (no page).

If there is a tradition of studies that is concerned on understanding the historical key to the sensibilities, then there is also a concern with its education, an important current object in the field of History of Education, as shown by the studies organized in two volumes by Dussel and Gutierrez (2006), Taborda de Oliveira (2012), Pineau (2014), and Braghini, Munakata and Taborda de Oliveira (2017) ${ }^{3}$

Many aspects can be suggested, but we will stick to three dimensions of what may be characterized as a turn in the direction of senses and sensibilities, which was certainly

\footnotetext{
3 The education of senses and sensibilities are boosted by the historical renovation experienced from the 1960s all around the world, even though it was already on the agenda of the first historians of the Annales (CORBIN, 2005), as we have seen, it was present in reference works in the field of History since, at least, the begging of the $20^{\text {th }}$ century. In the pedagogical field, it is worth noting the entries sensibilité/sentiments, and sens (Educatión des) in the Dictionnaire of Ferdinand Buisson (1911). Its recent importance in the field of history of education can be seen by the development of a table on the future of history of education, during the 33rd International Standing Conference for the History of Education, July 2011, in Mexico. The session entitled Historiografia del futuro: mirando atrás hacia el future - Historiography of the future: looking behind towards beyond, organized by Kate Rousmaniere and Frank Simon, presented the following works: História de las identidades - History of identities (MOCTEZUMA, 2011); História de los sentidos - History of senses (GROSVENOR, 2011), and Historia de la emociones - History of feelings (SOBE, 2011). It was also a highlight in the program of Congreso Iberoamericano de Historia de la Educación Latinoamericana, in Toluca, Mexico, May 2014, in a conference given by Grosvenor (2014). In the editions of Congreso Iberoamericano de Historia de la Educación Latinoamericana held in Rio de Janeiro (2009), Toluca (2014), and Medellin (2016) there were special work sessions about the theme. Those works were published in Taborda de Oliveira (2012). In the sessions of International Standing Conference for the History of Education, August 2016, in Chicago, many works were dedicated to this topic. There was even the creation of a SDW (Standing Work Group) on this theme entitled Objects, Senses and the Material World of Schooling. Based on these, plus the conference of the same institution held in Buenos Aires, July 2017, we can affirm that the history of education of senses and sensibilities (of affections, of emotions...) has become the new "fad" in the field of History of Education, as it had a significant (and impressive!) number of works submitted to that event which assume this designation, despite their contents or problems. More than a problem itself, the sensitive dimension seems to have become a descriptor.
} 
made possible by the renovation of studies in History of Education and its intense approximation in the field of History in Latin American, during, at least, the last 20 years. ${ }^{4}$

The first refers to a type of a saturation of histories of generalized character, if not, abstract. History of ideas, history of pedagogy, history of discourses can serve to many inherent domains of historical knowledge and should be valued as such. However, they have always kept us apart from what the people and social groups did with their ideas or their discourses, they are far from the materiality of life. What were the answers given by people, including common people, in different situations, to what the social, political, and economic structures intended to impose on their lives. How did they think the world and how did they react? How did they adapt or resisted? The emergency of this type of concern allowed historians of education to turn their eyes to the domain of practices, uses, ways of doing, thinking, acting, and feeling. How they dealt with the experiences, defined by Edward Thompson as "open exploration of the world" that happens in the "dialogue between being and social awareness". (THOMPSON, 1978). The experience is eminently corporeal, mobilizing all our perceptive apparatus in the definition of our sensibilities, as splendidly shown in the vast work of Walter Benjamin.

So, and this is a second import aspect, it was necessary to question the macroexplanations, all the generalization, so as to capture how, despite the innumerous prescriptions on how to organize life, it was actually organized from the shock of experiences between normative instances and individuals' ordinary lives. For example, if the State and the dominant elites have always tried to frame the lives of ordinary people, it is imperious to understand how they reacted to it, beyond understanding the discourses and normative prescriptions. That is, between the educational imperative that predicted a type of commonly standardized sensibility, as shown by Pineau (2014) and Mercado (2014), and the dynamics of life that proposed or presupposed competitive sensibilities (MEURER; TABORDA DE OLIVEIRA, 2015), every generalization started to be questioned from the need to change the scale of analysis, as it became mister to understand the emotional responses of different individuals faced to social imperatives, such as proposed by Febvre in the 1950s.

The third aspect, deeply related to the others, seems to be related to a new "inflection towards the individual", in the words of the philosopher Theodor Adorno. What can be called a sensitive turn seems to have been also developed by the concern with the individuals, groups, or singular populations over the traditional generalizing ways of understanding their formation processes. In this perspective Beltrán and Buitrago (2012) show us that the wish for silence prescribed by Colombian schools in the beginning of the 20th century had to face the "restlessness and impatience" of children, that did not passively gave in to regulating imperatives, be them moral or aesthetic. Similarly, the definition of femininity or masculinity, according to the studies of Sharagrodsky (2008) in Argentina, or the attempts of "juvenile emotional control" as suggested by Toro (2015) in Chile.

In this context of studies new forms of looking what happened inside the schools were developed (TABORDA DE OLIVEIRA, 2006, 2009; TABORDA DE OLIVEIRA;

\footnotetext{
4 I am not going to revise here the constitutive tradition of the field of History of Education in the different countries of the continent. There is a vast production on that, even in a comparative perspective. Despite the nuances, it seems clear that it has developed from a focus on pedagogical ideas, in legislative bases, and the analysis of discourses on and about education, the "material dimension", which supports the sensitive dimension, is forgotten or is in second place.
} 
BELTRÁN, 2008; DI PIETRO; PINEAU, 2008; BELTRÁN, 2012; MARTINS, 2014; TORO, 2015; MUNAKATA, 2012, 2017; BRAGHINI, 2017), but also new concerns with education in spaces and times outside the school, as proposed by Taborda de Oliveira (2014), Taborda de Oliveira and Oscar (2014), Arata (2014), and Costa (2014). Thus, it is fundamental to recognize how much the studies on the history of education of senses and sensibilities own to those studies related to the history of body education, of material culture, of school practices, of memory studies, etc. Therefore, if we are faced by a stimulating branch of studies in History of Education, we should recognize that, less than a new scope of studies and researches, the history of senses and sensibilities seemed to be spread in the underground of domains considered "nobler", hidden amongst other concerns and interest of education historians. The fact that the term "history of senses and sensibilities" has recently been assumed by many researchers does not invalidate the recognition that a lot of what has been researched from the historiographical renovation on the last decades considered, directly or indirectly, the inflection towards singular individuals, the narrowing in the scale of analysis of the processes of societal constitution, as well as the study of historical experiences beyond the ideas and discourses, without completely abandoning them.

Sensibilities would then be the ways through which individuals and groups can see themselves, appearing as a redoubt of representation of reality through emotions and senses. In this sense, he sensibilities are not only in the core of the process of representing the world, but correspond, to the culture historian, to the object that can be captured in the past, that is, the life energy itself, the enargheia, of Carlo Ginzburg. Historians have posed this problem, that passed through rescuing feelings, ways of acting and thinking of other men in another time, feeling that should be considered as an otherness to the historian. (PESAVENTO, 2005, no page).

\section{The history of senses and sensibilities in different educational spaces: beyond a history of school}

If the history of school has taken a privileged space in the research agenda of historians until very recently, today it is imperious to recognize the need for multiple approaches, problems, and questions that the history of education of senses and sensibilities can bring beyond the sphere of schooling. There are many efforts in different countries, with different levels of organicity, to historically understand the definition and the transformation of sensibilities in school education, but also regarding the times and spaces of social education. ${ }^{5}$ In the researches developed by the Núcleo de Pesquisas sobre a Educação dos Sentidos e das Sensibilidades - Nupes (Center for Studies on the Education of Senses and Sensibilities), a part of the Centro de Pesquisas em História da Educação GEPHE (Research Center on History of Education), at Universidade de Minas Gerais, Brazil, we established an agenda that is allowing us to explore some possibilities in this rich historical field of studies, producing masters and doctoral works, as well as stimulating postdoctoral researches, and forming young researchers through academic works.

This group owns a lot to a much broader set of interinstitutional relations. It was formalized in 2010, at UFMG, in Belo Horizonte, as a consequence of the results of another project developed since 2003 at Universidade Federal do Paraná, which focused on the

${ }^{5}$ On the notion of social education and its multivocality see: Tiana e Ferrer (2012), and Taborda de Oliveira and Oscar (2014). 
relations between curriculum and body education. ${ }^{6}$ Based on the results of that project, in 2008, during a research period at the Centro Internacional de la Cultura Escolar - Ceince (International Center of School Culture), in Berlanga de Duero, Spain, under invitation of Prof. Agustin Escolano Benito, we delimited a Project of investigation that is still fruitful (BRAGHINI; MUNAKATA; TABORDA DE OLIVEIRA, 2017), which had the history of education of senses as the main axis. From that point on, a productive partnership with Professors Kazumi Munakata e Katya Braghini was born, resulting in 4 seminars, in Sao Paulo and Belo Horizonte, many tables in national and international events, and the publishing of three books on the theme. This partnership presupposes an articulation involving researchers in Brazil and other countries, who are mobilized by the different possibilities of approaching historically the education of senses and sensibilities. ${ }^{7}$

Thus, this group is the prime example of a basic assumption: be it in the scientific, aesthetic, ethic, or political dimension, every intellectual work is necessarily a bet on sensibility, as it is about "exchanging experiences", sharing, walking together and with someone, do it together and do it with someone.

Regarding social education in the researches we have been developed, we can highlight, for instance, studies on rural education and the attempts to modernize rural areas through youth education (GOMES, 2014); on eugenics and its prescriptions for body education (GALAK, 2014); the campaigns to develop a popular sensibility able to enjoy the theater (REZENDE, 2013) or as a way to culturally resist Brazilian dictatorship (TABORDA DE OLIVEIRA, 2014); the use of photography and the world wide web in defining contemporary subjectivity (BARROS, 2013); the creation and circulation of pedagogical material in schools and museums (BRAGHINI, 2017; BRAGHINI; MUNAKATA, 2017); the development of a work ethos through workers' press (DRUMMOND; TABORDA DE OLIVEIRA, 2015); the use of poetry in the formation of readers (BORNATTO, 2017), or the exploration of the city as a way to educate corporal senses. (TABORDA DE OLIVEIRA; OSCAR, 2014).

In school contexts there are studies that focus, for instance, on the relation between physical education, nature, and education of senses (TABORDA DE OLIVEIRA, 2009, 2012), the historical creation of school breaks (MEURER; TABORDA DE OLIVEIRA, 2016), the use of didactic material on gymnastics in primary school (PUCHTA; TABORDA DE OLIVEIRA, 2015), the history of secondary school (OLIVEIRA, 2015), or even the limits of political education. (TABORDA DE OLIVEIRA; BIANCHINI, 2017). ${ }^{8}$

\footnotetext{
${ }^{6}$ It is the project Transformações nos padrões de manifestação e controle corporais na escola elementar paranaense na passagem do modelo doméstico para o modelo graduado (1982-1920), sponsored by CNPq and Fundação Araucária. It is worth highlighting the long-lasting partnership with Diogo Rodrigues Puchta, Sidmar dos Santos Meurer, and Sérgio Roberto Chaves Jr. Active researchers of Nupes/UFMG, interlocutors with whom I have the pleasure to discuss and learn for about 15 years.

${ }^{7}$ Among the researchers with whom I have been sharing experiences in these investigation, through all sorts of exchange programs in Latin America, I highlight Maria do Carmo Martins (Unicamp), Suzete de Paula Bornatto and Cristiane dos Santos Souza (UFPR), Mirian Jorge Warde (Unifesp), Alexandre Fernandez Vaz (Ufsc), Marcus Vinicius Carvalho Corrêa (UFF), Matheus Cruz e Zica (UFPB), Pablo Pineau, Belém Mercado, Eduardo Galak, Pablo Scharagrodsky and Angela Aisenstein (Argentina), Cláudia Ximena Herrera Beltrán (Colômbia), Edgar Spejel and Lucia Moctezuma (México), Raumar Rodrigues (Uruguai). It is auspicious to notice that this circle of exchange relations geared by a common interest has been increasing in the past 10 years.

${ }^{8}$ Other expressions of sensibilities education have emerged in the historiography of education since the 1990s. As an example, we can consider the works of Lopes and Gouvea (1999), Lopes and Galvão (2010),
} 
The concerns with this vast research program are connected in the articulation of a set of key words that move the researchers and their associates in other national and international institutions: work/labor, free time, social education, formation, and senses/sensibilities, plus the multifaceted concept of modernity. These key words are themselves the object of continuous scrutiny of the group, as its occurrence in the documents used should be the greatest guide on the possibility of its use. Therefore, its history is also in our horizon of concerns, be it in the perspective proposed by Koselleck (2006) or in the terms suggested by Williams (2000). Among those descriptors

[...] the notion of senses and sensibilities has been guiding our studies. Senses are understood as part of the biological apparatus, responsible for the primary perception of what surrounds us. Its education was one of the greatest goals of the pedagogical renovation movement around the world from the 1880s on [...] it can be inscribed in what we consider as possibilities for body education. In the $19^{\text {th }}$ century they meant [according to Portuguese language dictionaries], amongst other meanings, "the faculty that men and animal have to notice external impressions through certain organs". (TABORDA DE OLIVEIRA; OSCAR, 2014, p. 176).

As the stimulation of senses, when considered as windows to the world, is key to the constitution of the multivocality of historical experience, the considerations on this notion in our studies lead to the understanding of these relations and interactions with the sensibilities. Those are characterized by Portuguese language dictionaries in the $19^{\text {th }}$ century as

"[...] faculties of feeling and experiencing physical impressions inherent to the nervous system, through which men and animals can perceive the sensations caused by exterior objects or born within", they can be considered as educational domain as one can teach and lean about the uses of the body. However, if we consider one of its meanings, the one that defines a "faculty to experience moral impressions; disposition to experience impressions of this type", so one needs to recognize that sensibilities are the result of responses given by individuals from the moment they interact with the physical or social world. (TABORDA DE OLIVEIRA; OSCAR, 2014, p. 176).

These responses, on this study domain, allow us to question all those perspectives that have a great appeal in western tradition, to which only rationality would guide the actions of men and women throughout history, as suggested by Coccia (2010) and Esposito (2016). Studying the history of senses and sensibilities implies considering that not all answers given by individuals to the stimuli of the physical and social environments are guided by reason. As explained by Pineau (2014) reading the aesthetic dimension, it is the conversion of the "[...] sensorial world of subjects into certain sensibilities [...]". (PINEAU, 2014, p. 25). Still dialoguing with this author, we are interested in understanding how the subjects appropriate the world, so that what underlies the epithet of sensible or aesthetical can move towards ethical and political.

This observation is important as we deny any type of subjectivity in the study of senses and sensibilities, as sometimes observed in some field works. If the senses are the

Stephanou (1999), Mignot et al (2000), Bastos et al. (2002) although the expression sensibilities has not necessarily been mobilized in those works. But this production dealing with memories, readings, writings of the self, literature, among so many other themes, are expressions of the education of sensibilities beyond the school key. 
windows to the souls of singular individuals, allowing the decoding of a physical and cultural world, so they are eminently historical. Therefore, they are sociable, they are shared. It does not seem to make sense a separation between culture and nature, or individual and society, as their relations are inextricable. Only a schematic and "positivist" scientific claim could conceive individuals that are disconnected of social relations and cultural inheritance, so as culture as an opposition to nature or its incontestable overcome. Thus we define that

\begin{abstract}
It is exactly in the education of senses, as a creator of new sensibilities, that we find the process which we aim to interpret. It is on how this process happens, in what the remains of the past allow us to see, that we concentrate our efforts. In this search we understand that the senses and sensibilities are not exclusive domains of the spheres of culture or of "nature", even if the notion of this history itself should be treated carefully [...]. But we think the constitution of sense and sensibilities as a historical problem in a multifaceted perspective, as proposed by Lucien Febvre who, certainly not by chance, alluded to our "affective-motor complex". They are understood overlapped with politics, economy, and culture, with what our cultures and societies have kept from nature and from the physical world. A history of smells, the idea of hearing regression, or the ways we learn to walk, are not tangible marks of the interaction between the natural and the social world that survives and changes in us? When authoritarian or totalitarian regimes develop a terror technology based on pain and cruelty, isn't it because they had captured precisely that point which culture and nature get mixed? (TABORDA DE OLIVEIRA; OSCAR, 2014, p. 176177).
\end{abstract}

Thus, based on the understanding that sensibility deeply marks our experience and what we have seen, touched, smelt, or tasted is apprehended historically as well as defines, through our sensitive apparatus, what we will be, we follow the registers - in written texts, images, and sounds - that can allow us to understand the limits and possible reaches of what we have been calling the history of education of senses and sensibility, within the particularities that the historical environment allows us. We understand that sensibility is not a passive response of the subjects- individual or collective- to the influxes of the external world. It is the result of the action or the reaction of subjects to all sorts of senses stimuli, and it is, therefore, an active faculty. Hence, we search within the plurality of historical experiences the aspects that can clarify the permanence fluxes, but also the moments of transformation, when a particular type of experience gives place to other ways of seeing, knowing, feeling, and acting on the world. In what level individuals and groups have their experiences affected to the point of transforming not only themselves, but, perhaps, even the ways societies and cultures are organized.

\title{
3. What is the future of researches on the history of education of senses and sensibilities?
}

If this is a recent domain among the interests of education historian, seeming to configure itself a new academic trend, one needs to reflect not only on its potential and heuristic power to understand culture and society in its different fluxes of time and geographical demarcations. One needs to question what the "novelty" of history of education of senses and sensibilities can mean in the History of Education.

Considering the three aspects mentioned before, incrementing the studies in the perspective of the history of education of senses and sensibilities can mean refining the way one sees the slow constitution of acting and feeling - and, also thinking- born on the crossing 
of structural determinations and individual volition. Positioning itself against the arbitrary ways of conceiving the experience of different individuals or social groups- "alienated", "passive", "hostages of a false consciousness", "indifferent", or "victims". The historical study of sensibilities shows us that human actions and reactions have such a complexity that cannot be reduced by any simplistic rationalist scheme. This is true to the ways students and teachers resist the imperatives of school format, as well as the negotiations and transgressions of workers facing any type of injustice and violence of the job market, for example. Maybe the answers are not the ones expected by the rationalism of the academic world, or in the formulations of the great thinkers of education, civilization, and culture. But they are the answers given in certain contexts which we did not leave or even know, according to the instruments available to the men and women that act in the world in ways that are, sometimes, radically different from those we would act or would like to act. Thus, we can learn something from a popular song:

Ao longe a voz das lavadeiras / On the background the voice of the washerwomen Ensina cedo a força do viver / Teaching early the strength to live Quem viu corer / Who has seen

O Jequetinhonha para o mar / The Jequetinhonha flow to the ocean Quem lava com o suor a nossa roupa / Who washes with sweat our clothes Tece o destino, quebra canoa / Weaves the destiny, breaks the canoe

A vida tece um sonho só. / Life weaves only a dream. (ORNELAS; MOURA; ANTUNES, 1994).

It seems that to recognize the plurality and the multivocality that reaches us from the past is, in itself, a political aspiration in an environment that habitually gives voice primarily to those around or in the centers of power. Therefore, one needs to be careful with a risk offered by the history of sensibilities when it becomes one more fad, one rich commodity in the academic market: its political deflation. Moved by some type of curiosity or by an unstoppable desire for the mild or the irrelevant, thus, for the ephemeral, many researchers sprout a hyper subjectiveness that hinders any type of analysis or project in which politics and common culture make sense, as if individuals acted in the world with complete autonomy or independence of society or culture. The sensitive responses of individuals and groups to the influxes they receive from the exterior world through the senses are, as we have seen, exactly the answers to what the physical and the social worlds propose, impose, request, and demand from these individuals or groups. So, they are always sensibilities forged in certain ambience, but also particular responses. They are, however, always produced in relation to someone or something, always by someone or by something. Thus, it is not about eliminating the ethical and political dimension by glorifying self-centered individuals, but, on the contrary, to show how ethics and politics are built in active life, in the interaction between individuals, in a tense and many times conflicted effort of mutual understanding on what the world, life, and society is or could be. ${ }^{9}$

\footnotetext{
9 If in the relation culture - individual, the idea of collectiveness has been set for a while, when it comes to common culture (WILLIAMS, 2003), we see a different scenario nowadays. There may be an overexageration on the idea that the individual creates itself, makes itself, produces itself, is its "own company", what marks this strong imaginary that "to each its own", independently of any type of social exchange or sociocultural environment. If contemporaneity presents us with this possibility of societal organization, so the history of education of senses and sensibilities gets political relevance in the attempt to understand where, how, when, and why common practice cultures were overpowered by an exaggerated individualism. That is why I emphatically criticize all production that considered the individual as monad, with
} 
At this moment, enters in stage the subjectivity of the historian, his/her capacity of otherness. As in other domains of history, he/she can only understand the past by making an effort to understand how certain responses- sensibilities- were given to a certain problem offered by human perceptive apparatus- via senses- through a dialogic attitude with the experiences of other times, and nor as a mere uninterested spectator, distant or objective. That is why "to work with the expression- or even, the impressions or marks left by life, with the psychologism of a time, with the sensibilities- multiple, changeable, unstable, varied- of men from another period of time can be an obstacle, but also a great attraction". (PESAVENTO, 2005, no page).

It is exactly the strangeness towards the way individuals form the past reacted, created, lived, felt, that leads historians to search those occult - and unvalued - meanings, expressed in the different types of sensibility - aesthetic, political, ethical, moral - and in the transformation of individual and collective life. To do so it is not enough to "know and describe the context" or have sources. One needs to reconstruct all ways of conceiving life in a certain environment, not only the prevailing one, but also the ordinary and hidden ones, so as to capture why people reacted in a certain way to certain stimuli, sometimes very similarly and other times in open opposition. The fascination in understanding this dynamic game between the singular and the social can only make us understand the past in terms of verisimilitude, as suggested by Ginzburg (1989b). What more, observing the evidences left by a documentation in which the senses and sensibilities are impressed as a residue and not as a clear and objective fact demands a capacity to extrapolate the obviousness of traditional registers. Quoting Droysen, Pesavento reminds us that

[...] it is only through the eyes of the historian that one can recognize the traces left by the past, elements to the research, to see in what is left the "footsteps of the spirit and the hand of men" from another time and that, the more prepared is the spirit that questions, the richer the content of the question. That is, [the author] emphasizes the previous accumulated knowledge, the erudition of each historian, that brighten his eyes and awakens the contemplation of a past world, what creates in me, spectator and reader, an awakening and a type of benjaminian revelation, is the meeting if a stadium background with the emotional/evocative/relational baggage of the punctum. (PESAVENTO, 2005, no page). ${ }^{10}$

Of course that if the knowledge of the past is always indirect, it occurs through walking in slippery ground, aiming to fill the gaps that would allow our interaction with the experiences of the past, with the lives of men and women who thought and lived differently from us, so this is only possible through the approximation allowed by registers of past sensibilities left in all types of empirical material. The best translation of this imperative is the materiality of materials that we use as main sources to understand the education of

no windows to connect with the world. I am calling this a subjectivist perspective, which I oppose exactly because senses and sensibilities are always relational and contingent, even if they flourish and manifest themselves also in the singularity. I thank Professor Katya Braghini for emphasizing this aspect.

10 On the notions of studium and punctum, see the studies of Barthes (1984) on photograph. The allusions of the author towards the reflections of Barthes are very appropriate. Exactly because the author defines studium as the broad scope of culture and knowledge that is always shared. It's the domain par excellence of understanding, of (re)cognition, of the previous knowledge we use into the world. Punctum, on the contrary, emanates from things and affects us, marks us, injury us in a particular way. From the meeting of these two types of stimuli the sensibilities are produced, including the one that makes the historian able to understand what is not in the complete realm of rationality. Very similarly, Berger (2000) reminds us that "la vista llega antes que las palavras" ("the sight arrives before the words"). 
senses and sensibilities. Once more, Pesavento observes one of the main challenges of the historians of sensibilities:

So that he/she can create a version of the past, one needs to find the external translation of such sensibilities generated within the individuals. That is, even the most refined sensibilities, the emotions and feelings, should be expressed and materialized in some type of register that can be unveiled by the historian. There is, therefore, the basic requirement of making history: the need for a narrative that is founded on the traces of historicity, or the sources and registers of something that happened and that, once organized and interpreted, will give proof and legitimacy to the historiographical discourse. (PESAVENTO, 2005, no page).

Therefore, the research on the history of education of senses and sensibilities requires the same methodological scrutiny claimed by any other domain of history. But it is vital to recognize that it is not enough to go to the sources expecting to find in them forged sensibilities, transformed, in dispute. Due to their hidden and intangible traces, understanding the sensibilities of the past demands an understanding of a world in constant transformation, in which the experience is observed not in linear flows of time, but in shrapnel that confuse the views; in which individuals affirm their ways of living against any type of constraint, even if those manners do not please those researchers who are incapable of a slight sense of otherness towards the experiences of men and women from other times and spaces; in which the complexity of life and the social world was shown entirely beyond the games prescribed by governments and dominant social groups.

Finally, the history of education of senses and sensibilities is not only a way to shed light to old problems, even because, despite its status as an "academic fad", it is not so new. However, it allows us to formulate not only different questions to old problems, but also new problems towards what we call education, be it in its institutionalized ways or not. New problems that arise from the gaps of a historiography that conceived education only as the transmission of ideas, normally, from few countries considered "civilized"; the illiteracy as an unquestionable trace in social hierarchy; the school rituals taken as "normal" and not as the expression of a possible socio-educational perversity; the school as the final expression of education, and not as one of the many possibilities to understand educational practices in a society, be it a literate one or not; education as always having a positive meaning, as if the processes of "civilization" of behaviors or disciplining were not tangible marks of a violence against which individuals and groups have constantly reacted against, even as a way to affirm their ways of being, living, and feeling the world faced by other ways that were considered more civilized, adequate, or necessary to those groups that were used to understand the other as the rest, what is left, what is outside, worthless, as it is evident in Latin America.

Sensibilities are expressed in acts, in rituals, in words and images, in material life objects, in materialities of the space built. They express the real and the unreal, what is known and what is not, what is intuited, sensed, or made up. Sensibilities are connected to an imaginary world, to culture, and its set of constructed meanings about the world. Even if such sensitive representations refer to something that does not have a real proved existence, what is been discussed and analyzed is the reality of feeling, the sensitive experience of living and facing that representation. Dreams and fears, for instance, are real as feelings, even if their reasons and motivations, in this case, do not have a real consistence. (PESAVENTO, 2005, no page). 
The unveiling of this constant struggle between different sensibilities and, commonly competitive, would be a sufficient stimulus to try to overcome the "same- as- always" in history of education, valuing the polyphony of past experiences beyond academic fads, beyond an Eurocentric perspective, which allows us to move forward the meaning of history of education in a continent constantly attacked by all types of endemic violence, historically produced, that are often attenuated by narratives that treat education as a beacon for a better world. To whom does this beacon serve and what price is paid for it? Maybe the understanding of the history of sensibilities in dispute in our continent can help us understand the multiple meanings of education mobilized, including those that were silenced.

\section{References}

ARATA, Nicolás. Formar lectores: sensibilizar espíritus. La organización de la Biblioteca Nacional de Maestros (1870-1906). In: PINEAU, Pablo (Dir.). Escolarizar lo sensible. Buenos Aires: Teseo, 2014.

BAKHTIN, Mikhail. A cultura popular na Idade Média e no Renascimento. São Paulo: Hucitec-Brasília, Edunb, 1999.

BARRÁN, José Pedro. Historia de la sensibilidad en el Uruguay. Montevideo: Ediciones de la Banda Oriental, 2011.

BARROS, Gelka. Retratos imaginários: fotografia, tempo livre e indústria cultural. 2013. Dissertação (Mestrado em Estudos do Lazer) - Universidade Federal de Minas Gerais, Belo Horizonte, 2013.

BARTHES, Roland. A cámara clara: nota sobre a fotografía. Rio de Janeiro: Nova Fronteira, 1984.

BELTRÁN, Claudia Ximena; BUITRAGO, Berta Nelly. Escritos sobre el cuerpo en la escuela. Bogotá: Universidad Pedagógica Nacional, 2012.

BELTRÁN, Claudia Ximena Herrera. El pecado de la gula, los vícios, los excesos del sentido del gusto: hacia la historia de las relaciones entre la alimentación de la infância y la escuela colombiana a finales del siglo XIX y comienzos del siglo XX. In: TABORDA DE OLIVEIRA, Marcus Aurelio (Org.). Sentidos e sensibilidades: sua educação na história. Curitiba: Editora UFPR, 2012.

BENJAMIN, Walter. EI París de Baudelaire. Buenos Aires: Eterna Cadencia Editora, 2012.

Estética y politica. Buenos Aires: Las Quarenta, 2009.

Obras - libro 1, vol. 2. Madrid: Abada, 2008.

Rua de mão única/Infância berlinense: 1900. Belo Horizonte: Autêntica, 2013.

BERGER, John. Modos de ver. Barcelona: Editorial Gustavo Gili, 2000.

BORNATTO, Suzete. A aposta na poesia - antologias para crianças e jovens na década de 1960. IV Seminário Interinstitucional (UFMG/PUC-SP/UFPR) - Diálogos sobre a história da educação dos sentidos e das sensibilidades. 2017.

BRAGHINI, Katya; MUNAKATA, Kazumi. Fontes para a história da educação dos sentidos, numa abordagem transnacional. IV Seminário Interinstitucional (UFMG/PUCSP/UFPR) - Diálogos sobre a história da educação dos sentidos e das sensibilidades. 2017. 
BRAGHINI, Katya; MUNAKATA, Kazumi; TABORDA DE OLIVEIRA, Marcus Aurelio (Orgs.). Diálogos sobre a educação dos sentidos e das sensibilidades. Curitiba: Editora da UFPR, 2017.

BRAGHINI, Katya. As aulas de demonstração científica e o ensino da observação. Rev. bras. hist. educ., Maringá-PR, v. 17, n. 2 (45), p. 208-234, abr./jun. 2017.

BUISSON, Ferdinand. Dictionnaire de Pédagogie et d'Instruction Publique Primaire. 1911. Avaible in: $<$ http://www.inrp.fr/edition-electronique/lodel/dictionnaire-ferdinandbuisson/document.php?id=3807 >. Access in: 28 may 2017.

COCCIA, Emanuele. A vida sensível. Florianópolis: Cultura e Barbárie, 2010.

CORBIN, Alain. O prazer do historiador. Revista Brasileira de História, São Paulo, v. 25, n. 49, p. 11-31, 2005.

CORRÊA, Priscila Kaufmann; MARTINS, Maria do Carmo. Meninas peraltas: formação feminina em livros de literatura infantil. Educ. Temat. Digit., Campinas, v. 18, n. 2, p. 296312, abr./jun. 2016.

COSTA, Betina. Resonancias de una pedagogía para la guerra. Jordán Bruno Genta, educador de uma sensibilidade militar. In: PINEAU, Pablo (Dir.). Escolarizar lo sensible. Buenos Aires: Teseo, 2014.

DEMARTINI, Anne-Emmanuelle. Sensibilité(s). In: GAUVARD, Claude e SIRINELLI, JeanFrançois (Dirs.). Dictionnaire de I'historien. Paris: Presses Universitaires de France, 2015.

DRUMMOND, Caroline; TABORDA DE OLIVEIRA, Marcus Aurelio. A formação do trabalhador no jornal O Operário, de Montes Claros (1932-1945): a produção de novas sensibilidades "sem classes". In: MESQUITA, Ilka Miglio et al. (Orgs.). Moderno, modernidade e modernização: a educação nos projetos de Brasil - séc. XIX e XX. Belo Horizonte: Mazza, 2015.

DUSSEL, Inés; GUTIERREZ, Daniela. Educar la mirada. Buenos Aires: Manantial, FLACSO, 2006.

ELIAS, Norbert. O processo civilizador. Rio de Janeiro: Jorge Zahar, 1991. ESPOSITO, Roberto. As pessoas e as coisas. São Paulo: Rafael Copetti Editor, 2016. FEBVRE, Lucien. A sensibilidade e a história. In: Combates pela História. Lisboa: Presença, 1985.

FREYRE, Gilberto. Sobrados e mucambos. Rio de Janeiro: José Olympio, 1985 [1936].

GALAK, Eduardo. "Cuerpo", "sujeto" y "política" en la educación de los cuerpos argentina y brasilera: eugenesia y Educación Física entre las décadas de 1920 y 1930. Relatório de estágio pós-doutoral. Programa de Pós-Graduação em Educação e Inclusão Social, Universidade Federal de Minas Gerais, Belo Horizonte, 2014.

GAY, Peter. A educação dos sentidos. São Paulo: Companhia das Letras, 1999.

GINZBURG, Carlo. A micro-história e outros ensaios. Lisboa: Difel, 1989b.

. Investigando Piero. São Paulo: Cosac Naify, 2010.

. Mitos, emblemas, sinais. São Paulo: Companhia das Letras, 1989.

GOMES, Leonardo Ribeiro. "Progredir sempre": os jovens rurais mineiros nos Clubes 4S: Saber, Sentir, Saúde, Servir (1952-1974). 2014. Dissertação (Mestrado em Educação) Programa de Pós-Graduação em Educação: Conhecimento e Inclusão Social, Universidade Federal de Minas Gerais. Belo Horizonte, 2014. 
HUIZINGA, Johan. O outono da Idade Média. São Paulo: Cosac Naify, 2010.

JAEGER, Werner. Paideia. A formação do homem grego. São Paulo: Martins Fontes, 1986.

KOSELLECK, Reinhart. Futuro passado. Rio de Janeiro: Contraponto: PUC/Rio, 2006.

LOPES, Eliane Marta Teixeira. Colonizador Colonizado: Uma relação educativa no movimento da história. Educação \& Realidade, p. 23-32, 1990.

LOPES, Eliane Marta Teixeira; GALVÃO, Ana Maria de Oliveira (Orgs.). Histórias de meninas. Meninas de Sinhá. 1. ed. Belo Horizonte: Duo Editorial, 2010. v. 1.

LOPES, Eliane Marta Teixeira; GOUVEA, Maria Cristina Soares (Orgs.). Lendo e escrevendo Lobato. Belo Horizonte: Autêntica, 1999.

MARTINS, Maria do Carmo. Reflexos reformistas: o ensino das humanidades na ditadura militar brasileira e as formas duvidosas de esquecer. Educ. rev., n. 51, p. 37-50, mar. 2014.

MERCADO, Belén. Escolarizar la mirada: arte, estética y escuela (1880-1910). In: PINEAU, Pablo (Dir.). Escolarizar lo sensible. Buenos Aires: Teseo, 2014.

MEURER, Sidmar; TABORDA DE OLIVEIRA, Marcus Aurelio. A invenção dos recreios nas escolas primárias paranaenses: o lugar da educação do corpo, dos sentidos e das sensibilidades na escola. Rev. Bras. Educ., v. 21, n. 64, p. 225-247, mar. 2016.

MIGNOT, Ana Cristina Venâncio et al. (Orgs.). Refúgios do eu: educação, história, escrita autobiográfica. Florianópolis: Mulheres, 2000.

MUNAKATA, Kazumi. Que coisa é coisa das lições de coisas? In: TABORDA DE OLIVEIRA, Marcus Aurelio (Org.). Sentidos e sensibilidades: sua educação na história. Curitiba: Editora UFPR, 2012.

OLIVEIRA, Bruna. Gonzaga Duque e Revoluções Brasileiras: um olhar para a História do Brasil. 2015. Dissertação (Mestrado em Educação) - Programa de Pós-Graduação em Educação: Conhecimento e Inclusão Social, Universidade Federal de Minas Gerais, Belo Horizonte, 2015.

OSPINA, William. Las auroras de sangre. Bogotá: Grupo Editorial Norma, 1998.

. La escuela de la noche. Bogotá: Grupo Editorial Norma, 2008.

ORNELAS, Nivaldo; MOURA, Tavinho; ANTUNES, Murilo. Os aventureiros do São Francisco. CD. Warner do Brasil, 1994.

PESAVENTO, Sandra. Sensibilidades no tempo, tempo das sensibilidades. Nuevo Mundo Mundos Nuevos [En ligne], Colloques, mis en ligne le 04 février 2005. Available in: <http://nuevomundo.revues.org/229>. Access in: 29 may 2017.

PINEAU, Pablo (Dir.) Escolarizar lo sensible. Buenos Aires: Teseo, 2014.

PINEAU, Pablo; DI PIETRO, Suzana. Aseo y pesentación: un ensayo sobre la estética escolar. Buenos Aires: el autor, 2008.

PUCHTA, Diogo; TABORDA DE OLIVEIRA, Marcus Aurelio. O livro como ferramenta pedagógica para a inserção da educação física e da ginástica no ensino público primário paranaense (fim do século XIX e início do século XX). Rev. Bras. Ciênc. Esporte, 37 (3), p. 272-279, 2015.

REZENDE, Nadia Bueno. A campanha de popularização do teatro e dança em Belo Horizonte e o lazer: o diálogo com a cidade (1998-2012). 2013. Dissertação (Mestrado em Estudos do Lazer) - Universidade Federal de Minas Gerais, Belo Horizonte, 2013. 
SHARAGRODSKY, Pablo (Comp.). Governar es ejercitar. Buenos Aires: Prometeo,2008.

STEPHANOU, Maria. Governar ensinando a governar-se: medicina e educação. In: Luciano Mendes de Faria Flho (Org.). Pesquisa em história da educação: perspectivas de análise, objetos e fontes. Belo Horizonte: HG Edições, 1999, p. 153-168.

TABORDA DE OLIVEIRA, Marcus Aurelio (Org.). Educação do corpo na escola brasileira. Campinas: Autores Associados, 2006.

TABORDA DE OLIVEIRA, Marcus Aurelio; BELTRÁN, Cláudia Ximena Herrera. Uma educação para a sensibilidade: circulação de novos saberes sobre a educação do corpo no começo do século XX na Ibero-América. Rev. bras. hist. educ., Campinas-SP, v. 13, n. 2 (32), p. 15-43, maio/ago. 2013.

TABORDA DE OLIVEIRA, Marcus Aurelio; BIANCHINI, Paolo. Educação política no Brasil e na Itália: duas histórias, muitos problemas comuns. Hist. Educ., Porto Alegre, v. 21, n. 52, p. 274-294, maio/ago. 2017.

TABORDA DE OLIVEIRA, Marcus Aurelio; OSCAR, Luisa Belotti. Referenciais teóricometodológicos nas pesquisas em história da educação: para uma história das relações entre sensibilidades, tempo livre e formação. Revista Esboços, Florianópolis, v. 21, n. 31, p. 171-193, ago. 2014.

TABORDA DE OLIVEIRA, Marcus Aurelio. "Eu desisto?" Paredes vivas na cidade: conflitos sociais em cartazes produzidos ao longo da década de 1980, no Brasil. Educ. rev., n. 51, p. 175-190, mar. 2014.

Atividade e natureza: a educação física para o ensino primário. In: BASTOS, Maria Helena Camara; CAVALCANTE, Maria Juraci (Orgs.). $\mathbf{O}$ curso de Lourenço Filho na Escola Normal do Ceará. Campinas: Alínea, 2009.

2012.

Sentidos e sensibilidades: sua educação na história. Curitiba: Editora UFPR,

THOMPSON, Edward. A miséria da Teoria. Rio de Janeiro: Zahar, 1978.

Costumes em comum. São Paulo: Companhia das Letras, 1998.

1976.

William Morris: de romántico a revolucionário. Valencia: Alfons el Magnanim,

TIANNA FERRER et al. Historia de la educación social. Madrid: Uned, 2014.

TORO, Pablo Blanco. Algunas ideas exploratorias para una historia del control emocional juvenil en la educación secundaria chilena, c.1880-c.1950. In: SÁ, Elizabeth Figueiredo de; SIMÕES, Regina Helena Silva; NETO, Wenceslau Goncalves (Orgs.). Circuitos e fronteiras da história da educação. Vitoria: Edufes, 2015.

WILLIAMS, Raymond. Palabras-clave: um vocabulário de la cultura y la sociedade. Buenos Aires: Nueva Visión, 2000.

. La larga revolución. Buenos Aires: Nueva Visión, 2003.

ZUNTHOR, Paul. A letra e a voz. São Paulo: Companhia das Letras, 1993.

Escritura e nomadismo. Cotia, SP: Ateliê Editorial, 2005. 
MARCUS AURELIO TABORDA DE OLIVEIRA é professor na Universidade Federal de Minas Gerais (UFMG), Doutor em História e Filosofia da Educação pela Pontifícia Universidade Católica de São Paulo (PUC-SP).

Endereço: Rua Padre Demerval Gomes, 244 - ap. 203, 30535-470, Belo Horizonte/MG, Brasil.

E-mail: marcustaborda@pq.cnpq.br

Recebido em 21 de setembro de 2017.

Aceito em 16 de maio de 2018. 